\title{
Ethno-Medicinal Study of Plants Used for Treatment of Human and Livestock Ailments by Traditional Healers in Goba Woreda, Bale Zone, Oromia, Ethiopia
}

\author{
Habtamu Tedila* Getu Dida \\ College of Natural and Computational Science Department of Biology (Stream of Applied Microbiology and \\ Botanical science), Madda Walabu University, PO box 247, Bale Robe, Ethiopia
}

\begin{abstract}
The investigation of traditional medicinal plants was performed in Bale district from August to October 2018 in three kebeles Kedu, Elasa and Aloshe Tilo. In the study area diverse medicinal plant were used to treat many human and livestock disease. The data were collected from the informants through semi-structured interview, discussion and collected plant samples from the study areas that were used to treat different human and livestock ailments. A total of $\mathbf{2 1}$ informants were selected that consist of seven informants from each kebele of which $\mathbf{1 6}$ were males and 5 females. Among the informants six of them were key informants selected by purposive sampling method. A total of 35 medicinal plant species were collected from the study area and identified using the Flora of Ethiopia and Eritrea (volume 3, 1989). The medicinal plant collected was used to treat six disease categories. Namely, dermatological, respiratory, ureno-genital, gastro-intestinal, febrile and livestock disease. The frequently applied plant part was leaf (58\%) followed by root (25\%). Traditional healers commonly used the juice of fresh leaf and root of medicinal plants. To prepare it fresh part of the plant was crushed and the juice applied orally, nasally or dermally. However; these plant species were threatened by the activities of the community like expansion of agriculture, overgrazing, cultivation of eucalyptus tree as cash plant and application of the root of medicinal plant was a factor that needs risk of extinction. To conserve the biodiversity of the area and preserve the medicinal plants it was recommended to make aware of the society and to develop in -situ and ex-situ conservation of medicinal plants.
\end{abstract}

Keywords: Human diseases, Livestock ailments, Traditional medicinal plants, traditional healer. DOI: $10.7176 / \mathrm{ALST} / 71-03$

\section{INTRODUCTION}

Million years back, plants have been used in the health care systems of mankind (Khandel et al., 2012). Even today, plants remain the source for majority $(80 \%)$ of people in developing countries to alleviate health problems. Despite the notable progress in the synthetic of organic chemistry, more than $25 \%$ of agreed medicine of developed countries is also directly or indirectly derived from plants (Hostettmann and Marston, 2002).Furthermore, many of the major modern drugs such as quinine, salicylic acid, Artemisia have been discovered from traditional knowledge of communities (Yadav, 2013). Besides their use in preventing and curing various ailments, some medicinal plants are serving as export commodities, source of considerable income for farmers (Assefa and Abebe, 2014).

Ethiopia located in the horn of Africa is believed to be home for about 6,500 species of higher plants of which $12 \%$ are endemic(UNEP, 1995) making the country among the most diverse floristic regions of the world. Since Ethiopia is home to several languages, cultures and beliefs (Gidey, 2001), several traditional knowledge and use of medicinal plant practices are highly expected (Getaneh and Girma, 2014).

Studies show that, $80 \%$ human and $90 \%$ livestock in Ethiopia rely on traditional medicine for their primary health care systems (Yadav, 2013). Not only Ethiopians but also around $60 \%$ of world population depends on traditional medicine (Khandel et al., 2012). In developed countries such as United States, plant drugs constitute as much as $25 \%$ of the total drugs, while in fast developing countries such as China and India, the contribution is as much as $80 \%$ (Joy et al.,1998). The reason for highly reliance on traditional medicine in developing countries particularly in Ethiopia is cultural acceptability, effectiveness against certain type of ailments, accessibility and affordability as compared to modern medicine (Awas and Demissew, 2009; Yirga,2010;Megersaet al.,2013). Regardless of its contribution to the society, traditional medicine has been given a little attention in modern research and less effort has been made to promote the practice in Ethiopia (Gidey, 2001). Due to natural and anthropogenic factors, the biodiversity as well as medicinal plants are being depleted in an alarming rate (Megassa et al., 2013).

The current loss of medicinal plants in the country links with the missing of valuable indigenous knowledge associated with the plants (Zenebe et al.,2012). Among natives of various countries, knowledge of medicine has been Passed orally from one generation to the next by priests and medicine men (Getahun, 1976).But, due to the fact that cultural systems are highly fragile the skills are likely to be lost in the transfer process (Getaneh and Girma, 2014).Furthermore, the local communities encounter cultural changes due to development activities in 
areas where these communities reside and both the medicinal plants and the associated indigenous knowledge could vanish forever(Belayneh et al. 2012). This also holds true in Ethiopia where written records in this field are almost absent even though the country has had a written language for over thousand years (Agisho et al., 2014). In Ethiopia medicinal plants and knowledge of their use provided a vital contribution to human and livestock health care needs throughout the country the reason why medicinal plants are demanded in Ethiopia is due to culturally linked traditions (Kibebew, 2001). Ethiopia geographical diversity with different habitats and vegetation type's favors medicinal plant growth and utilization (Gebeyehu et al., 2013).Multiple geographical diversity of the country coupled with multiethnic group make it home for wide traditional medicine. The practice of traditional medicine in the country is not only concerned with curing of diseases but also with the protection and promotion of human physical, spiritual, social, mental and material well-being .

The knowledge involves traditional diagnosis, collection of raw materials, preparation of remedies and its prescription to the patients (WHO, 2002). Indigenous knowledge on remedies in many countries including Ethiopia, pass from one generation to the other generation verbally with great secrecy (Janzen, 1981). The complex knowledge, beliefs, and practice generally known as indigenous knowledge or traditional knowledge, develop and change with time. It includes time tested practices that developed in the process of interaction of human with their environment (Hunde et al., 2004). Indigenous people refer to people who follow traditional, non-industrial life style in area that they have occupied for generations (Balick and Cox, 1996). Indigenous knowledge is a result many generation long years' experience careful observation and trial and error experiments (Martin, 1995). Traditional people around the world possess unique knowledge of plant resources on which they depends for food, medicine and general utility (Martine, 1995, Khanal 2006 cited in Alemayehu, 2013). The knowledge helps them to identify and use many plants for traditional medicine to treat different human and livestock diseases.

The world health organization (WHO, 2002) defined traditional medicine as the total combination of knowledge and practice that can be formally explained are used in prevention and elimination of physical , mental, or social imbalance and relaying exclusively on practical experience and observation handed down from generation to generation whether, verbally or in writing (Amenu,2007). Traditional medicine as a major African socio cultural heritage, obviously in existence for several hundreds of years, and the first choice of health care treatment for at least $80 \%$ of Africans who suffer fever and other common ailment (Elujoba et al., 2005).

Ethiopia is a country characterized by a wide range of climate and ecological condition, possesses enormous diversity of flora and fauna (Pankhurst, 2006). The country possesses a wide range potentially useful medicine plants, more extensive indeed than available in many other parts of the world (Yirga and Zeraburk. 2005). Popular knowledge of plant used by human is based on thousands of years of experience by trial and error people learn how to recognize and use plants, including those with a magic- religious function. In Ethiopia, even though the traditional medicinal practitioners are the best sources of information secret, only to be passed orally to their older son, at their oldest age (Janzen 1981) Due to its long period of practice and existence, traditional medicine has become an integral part of the culture of Ethiopian people (Amenu. 2007). According to (Abebe, 2001), there is a large magnitude of use and interest in medicinal plant in Ethiopia due to acceptability and bio medicinal benefits. In Ethiopia the long history use of medicinal plants is reflected in various medico -religious manuscripts produced on parchments and believed to have originated several centuries ago (Kibebew , 2001). Medicinal text books written in Geez and Arabic in Ethiopia between the 17 \& 18 centuries employs that plants have been used as a source of traditional medicine in Ethiopia health care system. In Ethiopia little emphasis has been given to traditional medicinal studies over the past decades (Hunde,et al.,2004). There for it can be said that ethinobotanical studies are merely at the start in Ethiopia there have been some attempts in investigating medicinal plants uses and there is as yet, no in depth study on the relation between medicinal plants and indigenous knowledge on sustainable management of such plant species.

\section{Materials and Methods}

\subsection{Description of the study area}

The study was conducted from October 2016 to February 2017 in three kebeles Kedu, Elasa and Aloshe Tilo in Goba districts of Bale zone, Oromia Regional State, South Eastern Ethiopia. Goba district was located at $445 \mathrm{~km}$ south east of Addis Ababa. The area was situated at $7^{\circ} 00^{\prime} \mathrm{N}$ and $39^{\circ} 58^{\prime}$ E Latitude and longitude respectively. The area has a typical vegetation type of undifferentiated Afromontane forests in Ethiopia and has a mean annual rainfall and temperature of $1218.64 \mathrm{~mm}$ and $10.26{ }^{\circ} \mathrm{C}$, respectively. The economic activities of the local people were primarily based upon mixed farming that involves pastoralism and cultivation of crops such as wheat and barley.

\subsection{Data Sources}

The traditional medicinal plant data were obtained from primary and secondary sources. The primary data were obtained by collecting of fresh specimens data in the study area. The secondary sources were obtained by 
referring to previous studies in the country and literature review.

\subsection{Methods of Data Collection}

\subsubsection{Semi-structured Interviewer Administered Questionnaire}

Lists of questions were prepared that covered in the discussion with the informants in a particular order. The interview was done and around these questions and some issues were raids depending on responses of informant. The language that was used frequently with the informants was Oromiffa (common language of the woreda) and Amharic. During the interview the information regarding local name of the medicinal plants, parts used, methods of preparation and mode of application were gathered.

\subsection{Plant Specimen Collection and Identification}

The available plant specimens were collected for each plant species and identification of some common and well known species was made in the field including the local name, specific name and habitat. The identification was done by using taxonomic key and volume 3 of the Flora of Ethiopia and Eriterea (Hedberg ,1989).

\subsection{Data Analysis}

In order to assess the distribution of the medicinal plants in the area, vegetation survey was carried out. It also provided one way of summarizing the knowledge of vegetation pattern. As the study encompasses large - scale area quadrant were used and a visual identification of the community type were established based on the dominance of some species. The community name was derived based on the tree or shrub with high synoptic value.

\subsubsection{Descriptive Statistics}

A descriptive statistical method percentage was employed to analyze and summarize the data on medicinal plants and associated knowledge. The most useful information gathered on medicinal plants reported by local people. medicinal value, application, method of preparation, route of application, disease treated, dosage, parts and habits used were analyzed through descriptive statistical analysis.

\section{Results}

For identification purpose the leaf sample of 35 medicinal plants were collected and among these 27 species were used for the treatment of human diseases while six species were used for livestock treatment. The rest two species were used to treat both human and livestock diseases. The traditional practitioners collected $(41.6 \%)$ of the medicinal plants from home gardens and (58.4\%) from the natural habitat. Among the medicinal plants 18 species were herbs followed by 13 species shrubs and other four species were trees. 
Table 1: List of Traditional medicinal plant species used to treat human and livestock disease

\begin{tabular}{|c|c|c|c|c|c|}
\hline S.No & Botanical Name & Local Name & Type & Human/Liv estock & Ailment treated \\
\hline 1 & Cacumisfici folius & Yemdir embauy & Herb & Human & Sudden stomach aech \\
\hline 2 & Clerodendrummy ricoides & Misrich & Shrub & Human & Allergic \\
\hline 3 & Acokanthera schimperi & Merenz & Tree & Human & Hepatitis \\
\hline 4 & Ajugainteg pifolia & Aqourarach & Herb & Human & Tonsillitis \\
\hline 5 & Aloe vera & Eret & Herb & Human & Wound \\
\hline 6 & Artemisia afra & Ariti & Herb & Human & Abdominal problem \\
\hline 7 & Asparagus scaberulus & Keskeso & Herb & Human & Burring wound \\
\hline 8 & Asparagus spp. & Serittee & Shrub & Human & Allergic \\
\hline 9 & Achyranthe saspera & Telenji & Herb & Livestock & Abagorba \\
\hline 10 & Calpurnia aurea & Digita & Shrub & Livestock & Cattle lice \\
\hline 11 & Clematis hirsute & Azoareg & Shrub & Human & Abdominal problem \\
\hline 12 & Acmellacau lirhiza & Yemdirberbere & Herb & Human & Tonsillits \\
\hline 13 & Croton macrostachyus & Bisana & Tree & Human & Wring worm \\
\hline 14 & Datura stramonium & Astenagir & Herb & Human & Dandruf \\
\hline 15 & Echinoops kabaricho & Kabaricho & Shrub & Both & Febrile illness \\
\hline 16 & Ecualptus globules & Nechbeharzaf & Tree & Livestock & Abagorba \\
\hline 17 & Foeniculum volgare & Insilal & Herb & Both & Urination problem \\
\hline 18 & Jasmrnum gusscaqberulus & Tembelel & Shrub & Human & Allergic \\
\hline 19 & Juniprus procera & Yeabeshatid & Tree & Human & Wound \\
\hline 20 & Kasanechea maerantha & Endwhula & Herb & Human & Boil \\
\hline 21 & Kasanechea maerantha & Endwhula & Herb & Human & Tonsillits \\
\hline 22 & Leggerato mentosa & Chikugn & Herb & Human & Common cold\& Influenza \\
\hline 23 & Lepldium sativum & Feto & Herb & Human & Abdominal problem \\
\hline 24 & Leucusma rtinicensis & Raskemir & Shrub & Human & Febrile illness(much) \\
\hline 25 & Nicotina tobacum & Timbaho & Herb & Livestock & Leech infection \\
\hline 26 & Ocimum gratissimum & Damakese & Shrub & Human & Febrile illness \\
\hline 27 & Osyris quadripartita & Keret & Shrub & Livestock & Cattle skin lesion \\
\hline 28 & Phytolacca dodecandre & Indod & Shrub & Human & Gonorrhea \\
\hline 29 & Rhusre tinorrhoea & Tilem & Shrub & Human & Hepatitis \\
\hline 30 & Rumex absyssinica & Mekimeko & Herb & Human & Wring worm \\
\hline 31 & Rummex crispus & Tult & Herb & Human & Stomach aech \\
\hline 32 & Strychno sinnocua & Engochit & Shrub & Human & Abdominal problem \\
\hline 33 & Rutacha chlepensis & Tenadam & Herb & Human & Abdominal problem \\
\hline 34 & Verbana of icinalis & Ajo & Herb & Livestock & Abagorba \\
\hline 35 & Withania sominfera & Gizawa & Shrub & Human & Febrile illness \\
\hline
\end{tabular}

\section{Medicinal plant parts used, method of Preparation and rout of application}

Most remedies $(58.3 \%)$ were prepared from leaves followed by root $(25 \%)$. The majority $(88.8 \%)$ of remedies were prepared from fresh plant parts (leaf or root) followed by dried plant parts; the leaf or root powder $(11.2 \%)$ and most common of remedial preparation was squeezing of the fresh leaf or root (33\%) followed by powdering $(13 \%)$ most of these medicine prepared remedies were applied orally (38.8\%) followed by dermal $(33.3 \%)$ and nasal $(11.1 \%)$. (Table 2). 
Table 2: Traditional medicinal plants parts used, method of preparation and rout of application

\begin{tabular}{|c|c|c|c|c|}
\hline $\mathrm{SN}$ & Botanical Name & Parts used & Method of preparation & $\begin{array}{l}\text { Rout of } \\
\text { application }\end{array}$ \\
\hline 1 & Achyranthe saspera & Leaf & Fresh leaf crushed & Orally \\
\hline 2 & Acmellacau lirhiza & Flower & Chewing fresh flower & Orally \\
\hline 3 & Acokanthera schimperi & Fresh leaf & Fresh leaf juice with honey & Orally \\
\hline 4 & Ajugaintegpi folia & Leaf & Fresh leaf & $\begin{array}{l}\text { juice Nasally or } \\
\text { orally }\end{array}$ \\
\hline 5 & Aloe vera & Leaf & Covering with internal part & Topically \\
\hline 6 & Artemisia afra & Shoot & Fresh shoot socked in water & Orally \\
\hline 7 & Asparagus scaberulus & Leaf & Polishing dry leaf powder & Topically \\
\hline 8 & Asparagus spp. & Leaf & Fresh leaf juice & Topically \\
\hline 9 & Cacumisfici folius & Root & Root powder with water / coffee & Orally \\
\hline 10 & Calpurnia aurea & Leaf & Fresh leaf juice & Topically \\
\hline 11 & Clematis hirsute & Root & Crushing fresh root \&socked in water & Orally \\
\hline 12 & $\begin{array}{l}\text { Clerodendrummy } \\
\text { ricoides }\end{array}$ & Leaf & Fresh leaf juice & Topically \\
\hline 13 & Croton macrostachyus & Young leaf & Fluid in young leaf & Topically \\
\hline 14 & Datura stramonium & Leaf & Fresh leaf juice & Topically \\
\hline 15 & Echinoops kabaricho & Root & Root smoke & Nasally/orally \\
\hline 16 & Ecualptus globules & Leaf & Fresh leaf crushed & Orally \\
\hline 17 & Foeniculum volgare & Leaf & Fresh leaf juce & Orally \\
\hline 18 & $\begin{array}{l}\text { Jasmrnumgussca } \\
\text { qberulus }\end{array}$ & Leaf & Fresh leaf juice & Topically \\
\hline 19 & Juniprus procera & Dry leaf & Polishing dry leaf powder & Topically \\
\hline 20 & Kaanchea macrantha & Leaf & Covering with hot fresh leaf & Topically \\
\hline 21 & Kasanechea maerantha & Root & Fresh root crushed and socked in water & Nasally \\
\hline 22 & Leggerato mentosa & Leaf & Fresh leaf boiled with milk & Orally \\
\hline 23 & Lepldium sativum & Seed & Seed powder with water & Orally \\
\hline 24 & Leucusma rtinicensis & Leaf & Fresh leaf juice with water drop & Nasally \\
\hline 25 & Nicotina tobacum & Leaf & Fresh leaf juice & Orally or nasally \\
\hline 26 & Ocimum gratissimum & Leaf & Fresh leaf juice with water drop & Nasally or orally \\
\hline 27 & Osyrisqua dripartita & Leaf & Fresh leaf juice & Topically \\
\hline 28 & Rhmnus prinoids & Leaf & Chewing & Orally \\
\hline 29 & Rhusretino rrhoea & Leaf & Fresh leaf socked in water & Orally \\
\hline 30 & Rumex absyssinicus & Root & Root powder with butter & Topically \\
\hline 31 & Rummex crispus & Root & Chewing fresh/dry root & Orally \\
\hline 32 & Ruta chalepensis & Shoot \& fruit & Fresh shoot socked in water & Orally \\
\hline 33 & Strychno sinnocua & Root & Fresh root crushed \&socked in water & Orally \\
\hline 34 & Verbana of icinalis & Leaf & $\begin{array}{l}\text { Fresh leaf crushad\&mixed with the } \\
\text { above two }\end{array}$ & Orally \\
\hline 35 & Withania sominfera & Root & Dry root smoke & Orally \&nasally \\
\hline
\end{tabular}

\section{Traditional medicinal plants used to treat different disease categories} Dermatological diseases

The skin can be exposed to much pathogenic infection mainly to different fungal diseases such as ringworm, dandruff and skin allergic. The society in the study area used a number of medicinal plants to treat these and other dermatological ailments. About $10(27 \%)$ traditional medicinal plant identified used to treat different dermatological diseases. The fresh leaf is the most common parts of the plant for this purpose (Table 3). 
Table 3: medicinal plants used to treat human dermatological diseases

\begin{tabular}{|l|l|l|l|l|l|l|}
\hline SN & Botanical Name & Local Name & $\begin{array}{l}\text { Ailments } \\
\text { treated }\end{array}$ & $\begin{array}{l}\text { Parts } \\
\text { used }\end{array}$ & Method of preparation & $\begin{array}{l}\text { Rout } \\
\text { application }\end{array}$ \\
\hline 1 & Aloe vera & Eret & Wound & Leaf & $\begin{array}{l}\text { Covering with the } \\
\text { internal part }\end{array}$ & Topically \\
\hline 2 & $\begin{array}{l}\text { Asparagus } \\
\text { scaberulus }\end{array}$ & Keskeso & Fire wound & Leaf & $\begin{array}{l}\text { Polishing dry leaf } \\
\text { powder }\end{array}$ & Topically \\
\hline 3 & Asparagus spp. & Tembelel & Allergic & Leaf & Fresh leaf juice & Topically \\
\hline 4 & $\begin{array}{l}\text { Clerodendrum } \\
\text { myricoides }\end{array}$ & Misrich & Allergic & Leaf & Fresh leaf juice & Topically \\
\hline 5 & $\begin{array}{l}\text { Croton } \\
\text { macrostachyus }\end{array}$ & Bisana & Ring worm & Leaf & Fluid in young leaf & Topically \\
\hline 6 & Datura stramonium & Astenagir & Dandruf & Leaf & Fresh leaf juice & Topically \\
\hline 7 & $\begin{array}{l}\text { Jasmrnumgussca } \\
\text { qberulus }\end{array}$ & Tenbelel & Allergic & Leaf & Fresh leaf juice & Topically \\
\hline 8 & Jinuprus procera & Yabeshatid & Wound & Leaf & Leaf powder & Topically \\
\hline 9 & $\begin{array}{l}\text { Kaanchea } \\
\text { macrantha }\end{array}$ & Endwhula & Boil & Leaf & $\begin{array}{l}\text { Covering with hot fresh } \\
\text { leaf }\end{array}$ & Topically \\
\hline 10 & Rumex absyssinicus & Mekmeko & Ring worm & Root & Root powder with butter & Topically \\
\hline
\end{tabular}

\section{Respiratory diseases}

Respiratory diseases were the common health problem to the intended area of the study. People around that area treat the using traditional medicinal plant species. Of the plants identified from the study area six $(10 \%)$ were used to treat respiratory ailment like tonsillitis, common cold and influenza. (Table 4).

Table 4: Medicinal plants used to treat human respiratory disease

\begin{tabular}{|l|l|l|l|l|l|l|}
\hline SN & Botanical Name & Local Name & $\begin{array}{l}\text { Ailments } \\
\text { treated }\end{array}$ & $\begin{array}{l}\text { Parts } \\
\text { used }\end{array}$ & $\begin{array}{l}\text { Method } \\
\text { preparation }\end{array}$ & $\begin{array}{l}\text { Rout } \\
\text { application }\end{array}$ \\
\hline 1 & Acmella caulirhiza & Yemdirberbere & Tonsillitis & $\begin{array}{l}\text { Flower/ } \\
\text { root }\end{array}$ & $\begin{array}{l}\text { Chewing fresh } \\
\text { flower or root }\end{array}$ & Orally \\
\hline 2 & Ajugainteg pifolia & Aqourarach & Tonsillitis & Leaf & Fresh leaf juice & Nasally \\
\hline 3 & Ecualptus globules & Nechbeharzaf & Common cold & Leaf & Fresh leaf boild & Nasally/orally \\
\hline 4 & $\begin{array}{l}\text { Kasanechea } \\
\text { maerantha }\end{array}$ & Endwhula & Tonsillitis & Root & $\begin{array}{l}\text { Fresh root crushed } \\
\text { and socked in water }\end{array}$ & Nasally \\
\hline 5 & $\begin{array}{l}\text { Leggerato mentosa } \\
\text { Ruta chalepensis }\end{array}$ & Tenadam & $\begin{array}{l}\text { Common cold } \\
\text { \&Influenza }\end{array}$ & Leaf & $\begin{array}{l}\text { Fresh leaf boiled } \\
\text { with water }\end{array}$ & Orally \\
\hline 6 & Rumon cold & Leaf & $\begin{array}{l}\text { Fresh leaf boiled } \\
\text { with milk/tea }\end{array}$ & Orally \\
\hline
\end{tabular}

\section{Ureno-genital and organ diseases}

From the collected plant species four $(11 \%)$ of them were applied to treat uren- genital and organ diseases. Traditional healers used leaf and root for the treatment of ureno- genital and organ diseases. Crushing fresh leaf or root and preparing juice to be taken orally. ( Table 5).

Table 5: Medicinal plants used to treat Ureno genital

\begin{tabular}{|l|l|l|l|l|l|l|}
\hline SN & Botanical Name & Local Name & Ailments treated & $\begin{array}{l}\text { Parts } \\
\text { used }\end{array}$ & $\begin{array}{l}\text { Method } \\
\text { preparation }\end{array}$ & $\begin{array}{l}\text { Rout } \\
\text { application }\end{array}$ \\
\hline 1 & Acokanthera schimperi & Merienz & Hepatitis & Leaf & Fresh leaf & Orally \\
\hline 2 & Foeniculum volgare & Insilal & Urinary problem & Leaf & Fresh leaf juice & Orally \\
\hline 3 & Phytolacca dodecandre & Indod & Gonorrhea & Root & $\begin{array}{l}\text { Crushing fresh root } \\
\text { and socked in water }\end{array}$ & Orally \\
\hline 4 & Rhusretino rrhoea & Tilem & Hepatitis & Leaf & $\begin{array}{l}\text { Fresh leaf socked in } \\
\text { water }\end{array}$ & Orally \\
\hline
\end{tabular}

\section{Gastro intestinal disease}

In the study area indigenous people use many traditional medicinal plants to treat gastro-intestinal ailments. Oral application is the most commonly rout of remedies some of these plants are familiar the society in the study area. From identified medicinal plants seven (19.4\%) are used to treat these diseases. The root is the common part of the plant to prepare the remedies (Table 6). 
Table 6: Medicinal plants used to treat Gastro-intestinal disease

\begin{tabular}{|l|l|l|l|l|l|l|}
\hline No. & Botanical Name & Local Name & Ailments treated & $\begin{array}{l}\text { Parts } \\
\text { used }\end{array}$ & $\begin{array}{l}\text { Method of } \\
\text { preparation }\end{array}$ & $\begin{array}{l}\text { Rout of } \\
\text { application }\end{array}$ \\
\hline 1 & Artemisia afra & Ariti & Stomachaech & Shoot & $\begin{array}{l}\text { Fresh shoot socked } \\
\text { in water }\end{array}$ & Orally \\
\hline 2 & Cacumis ficifolius & Ymidrimbauy & Typhoid & Root & $\begin{array}{l}\text { Root powder with } \\
\text { water / coffee }\end{array}$ & Orally \\
\hline 3 & Lepldium sativum & Feto & Abdomenal problem & Seed & $\begin{array}{l}\text { Seed powder with } \\
\text { water }\end{array}$ & Orally \\
\hline 4 & Rummex crispus & Tult & $\begin{array}{l}\text { Sudden abdomenal } \\
\text { problem }\end{array}$ & Root & Chewing fresh root & Orally \\
\hline 5 & Rutacha lepensis & Tenadam & Stomach aech & $\begin{array}{l}\text { Shoot } \\
\& \text { fruit }\end{array}$ & $\begin{array}{l}\text { Fresh shoot socked } \\
\text { in water }\end{array}$ & Orally \\
\hline 6 & Clematis hirsute & Azoareg & Abdomenal problem & Root & $\begin{array}{l}\text { Crushing fresh root } \\
\text { \&socked in water }\end{array}$ & Orally \\
\hline 7 & Strychno sinnocua & Engochit & Abdomenal problem & Root & $\begin{array}{l}\text { Fresh root crushed } \\
\text { \&socked in water }\end{array}$ & Orally \\
\hline
\end{tabular}

\section{Febrile disease}

Febrile diseases were common in the community they occur frequently, but treated with some medicinal plants. They were effective when applied together. The fresh leaves of these plants squeezed and with water / coffee. (Table 7).

Table 7: Medicinal plant used to treat human febrile disease

\begin{tabular}{|c|c|c|c|c|c|c|}
\hline $\mathrm{SN}$ & Botanical Name & $\begin{array}{l}\text { Local } \\
\text { Name }\end{array}$ & $\begin{array}{l}\text { Ailments } \\
\text { treated }\end{array}$ & $\begin{array}{l}\text { Parts } \\
\text { used }\end{array}$ & $\begin{array}{ll}\text { Method } & \text { of } \\
\text { preparation }\end{array}$ & $\begin{array}{ll}\text { Rout } & \text { of } \\
\text { application }\end{array}$ \\
\hline 1 & $\begin{array}{l}\text { Echinoops } \\
\text { kabarichomesfin }\end{array}$ & Kebericho & Febrile & Root & Dry root smoke & Nasally/Orally \\
\hline 2 & $\begin{array}{l}\text { Leucusma } \\
\text { rtinicensis }\end{array}$ & Raskemir & Febrile & Leaf & $\begin{array}{l}\text { Fresh leaf juice } \\
\text { withcoffee/water }\end{array}$ & Orally/nasally \\
\hline 3 & $\begin{array}{l}\text { Ocimum } \\
\text { gratissimum }\end{array}$ & Damakese & $\begin{array}{l}\text { Febrile } \\
\text { illness(much) }\end{array}$ & Leaf & $\begin{array}{l}\text { Fresh leaf juice } \\
\text { with water drop }\end{array}$ & Nasally or orally \\
\hline 4 & $\begin{array}{l}\text { Withania } \\
\text { sominfera }\end{array}$ & Gizawa & $\begin{array}{ll}\begin{array}{l}\text { Febrile } \\
\text { (much) }\end{array} & \end{array}$ & Root & Dry root smoke & Orally \&nasally \\
\hline
\end{tabular}

\section{Livestock disease}

Breeding livestock is one source of economy besides cultivating crops to the society of the study area. They treat different livestock diseases with a number of traditional medicinal plant species. Traditional healer treat the disease of livestock using medicinal plants six $(16.7 \%)$ of identified from the study area are used to treat different livestock ailment. (Table 8).

Table 8: Medicinal plant used to treat Livestock disease

\begin{tabular}{|l|l|l|l|l|l|l|}
\hline SN & Botanical Name & $\begin{array}{l}\text { Local } \\
\text { Name }\end{array}$ & $\begin{array}{l}\text { Ailments } \\
\text { treated }\end{array}$ & $\begin{array}{l}\text { Parts } \\
\text { used }\end{array}$ & Method of preparation & $\begin{array}{l}\text { Rout } \\
\text { application }\end{array}$ \\
\hline 1 & Achyranthes aspera & Telenji & Abagorba & Leaf & Fresh leaf crushed & Orally \\
\hline 2 & Calpurnia aurea & Digita & Cattle lice & Leaf & Fresh leaf juice & Topically \\
\hline 3 & Ecualptus globules & $\begin{array}{l}\text { Nech } \\
\text { beharzaf }\end{array}$ & Abagorba & Leaf & Fresh leaf juice & Orally \\
\hline 4 & Nicotina tobacum & Timbaho & $\begin{array}{l}\text { Leech } \\
\text { infection }\end{array}$ & Leaf & Fresh leaf juice & $\begin{array}{l}\text { Orally } \\
\text { nasally }\end{array}$ \\
\hline 5 & Osyrisquadripartita & Keret & $\begin{array}{l}\text { Cattle skin } \\
\text { lesion }\end{array}$ & Leaf & Fresh leaf juice & Topically \\
\hline 6 & Verbana officinalis & Atuch & Abagorba & Leaf & $\begin{array}{l}\text { Fresh leaf crushed \& mixed } \\
\text { with the above two }\end{array}$ & Orally \\
\hline
\end{tabular}

\section{Discussion}

The society in the study area used many medicinal plants to treat different human and livestock diseases. In the study area traditional medicine is used by traditional healers to solve the health problem of human and livestock. Traditional healers are using local medicinal plants to maintain human and livestock health. In the study area most medicinal plants $(80 \%)$ were collected from farm land, grazing land, up land forest, compared to $(20 \%)$ 
from home garden. The community may not so interest to grow all the medicinal plants in the home garden and ex-situ. This may be due to most medicinal plant is available in the wild area so that the traditional healers harvest them very easily. Medicinal plant species Clerodend rummyyicoi, Asparayus spp. and Jasmrnum gusscaqberulus are used to treat skin allergic mainly they are applied for infants. By cutting seven or nine young leaf from each plant species mixed and squeezed then applied dermally. Juniprus procera and Asparasgus caperulus are used to treat wounds which are caused by burning. The dry leaf powder mixed with butter is applied on the wound to prevent infection. The squeeze of Croton macrostachyus used to treat ring worm. Cover the wound with five to ten hot fresh leaves of Kalaneama crantha is used to discharge the pus. Acmellaca lihizais is used to treat tonsillitis by chewing fresh flower or root. Leggerata mentosa is used to treat common cold and influenza by boiling with milk and taken orally mainly for infants. Traditional healers treat urenogenital and organ ailment using different traditional medicinal plant species. Phytolacca dodecandre is used to treat one of the sexually transmitted diseases gonorrhea. For the treatment of gonorrhea fresh root of the plant crushed the squeeze taken orally. Foeniculum Volga reused to treat urination problem of both human and livestock. It applied by taking the fresh leaf squeeze orally. Crushing the fresh leaf of Rhusterti norrhoea and Ackantheras chimperi squeezed together mixed with honey and taken orally before breakfast to treat hepatitis. Some medicinal plants are familiar to the society in the study area to treat many gastrointestinal ailments. Chewing the fresh root of Rmmex crispus used to treat sudden abdominal problem (dingetgna). The root powder of Cacumis ficifolius with water / coffee used to treat typhoid. Most these plants are found easily around home gardens. There are some plant species found around house fences used to treat febrile diseases such as Leucusmarti nicensis and Ocimumgar tissimum fresh leaf squeeze with water/ coffee taken orally. The traditional healers estimate the dosage by taking seven leaves from each plant and mix together and the squeeze given to the paint. The society in the study area also treats livestock diseases by medicinal plants. Nicotina tobacum is used to treat leech infection. Fresh leaf juice taken orally/nasally to with drown the leech from the trachea as it close the trachea and cause cough to the cattle. Crushing Ecualptus globules, Achyranthe sapsera, and Verbana oficinalis together socked in water and taken orally to treat Abagorba. The fresh leaf squeeze of Calpurnia aurea applied dremily to kill cattle lice.

Traditional practitioners in the study area mostly use leaves $(63.8 \%)$, for preparing remedies followed by root $(22.2 \%)$. Most traditional remedies were prepared using fresh materials (leaves and root) compared with dried one. It may be expected that when the plant is dried it may loss some of its content by the effect of temperature change. Traditional healers prepare the traditional remedies using different traditional measurement to estimate the dosage of the remedies like counting the number of leaf or root, using containers for example to treat gonorrhea with Phytolacca dodecandre juice they use a coffee cup up to the volume cover the thumb or nail of the healer. In this study area traditional healers used medicinal plants to treat a number of diseases using leaf which might not threatened the plant .Using root however, will lead to extinction. Indigenous people were highly dependent upon plants for multiple applications that threatened diversity of medicinal plants.

In the study area deforestation, over grazing and expansion of agriculture including cultivating eucalyptus tree as cash plant affect the survival of medicinal plants. In the study area the conservation status of medicinal plant is limited, there is to need to aware the society for the proper attention to conserve the biodiversity including medicinal plants .for the welfare of future generation in a sustainable manner.

\section{Conclusion}

The study area Goba wereda has diverse medicinal plants that were used to treat various human and livestock diseases by the local communities. The wild plant habitats were the main sources of medicinal plants compared to home gardens. Currently medicinal plants availability was at risk due to different human activities such as agricultural expansion and cultivating eucalyptus tree for the source of income were the most visible threats in the study area. The indigenous knowledge of people has to be passed over to the next generation. To conserve the biodiversity of the area and preserve the medicinal plants there was a need to create awareness and develop in - situ and ex-situ conservation of medicinal plants. In particular rare species should be given conservation priority.

\section{REFERENCES}

Abebe, Dawit (2001). The role of medicinal plants in healthcare coverageOf Ethiopia. The possible benefits of integration. In; Conservation and sustainable use of medicinal plants In Ethiopia. Pp.6-21.( Medhne Zewdu and Abebe Demissieeds). Proceeding of the National.

Agisho H, Osie M and Lambore T (2014).Traditional medicinal plants utilization, management and threats in Hadiya Zone, Ethiopia.Journal of Medicinal Plants Studies.2:94-97.

Alemaehu Getu (2013). Plant biodiversity and ethno botany in Amaro and Gelanawereda Southern Ethiopia with emphasis on .Medicinal and edible plants.Pp.13.

Amenu, Endalew (2007) Use and manegment of medicinal plants by Indigenous people people of Ejaji 
area(Chelya wereda) West shoa, Ethiopia. An ethno botanical approach. MSc thesis. AAU. Ethiopia.

Assefa A and Abebe T (2014).Ethnobotanical Study of Wild Medicinal Trees and Shrubs in Benna Tsemay District, Southern Ethiopia.J of Sci \& Devel 2(1).

Awas T and Demissew S (2009). Ethnobotanical study of medicinal plants in Kafficho people,southwestern Ethiopia. In: Proceedings of the 16th International Conference of Ethiopian Studies, (ed. by Svein Ege, Harald Aspen, Birhanu Teferra and Shiferaw Bekele) Trondheim.

Balick, M. J. and Cox, P. A. R. (1996). Plants People and Culture:he science of Ethno botany.ScientificAmerican Library.New York. USA. Pp.219. emissieeds). Proceeding of the National. Farnsworth NR. Ethnopharmacology and Drug Development. In:Ethno biology and the search for new Drugs. WilyChichester (Ciba Foundation Symposium. Chigago.SA.1994;185; 42-59.

Elujoba A.A., OdeleyeandC O.M.Ogunyemi M.(2005). Traditional medicine development for medical and dental prymery health care delivery system in Africa.Afr. J.Trad.Cam(2005)2(1)46-61.

Gebeyehu, Getaneh ,Asfaw, Zemede , Enyew, Abiyu ( 2013). EthnoBotanical study of traditional medicinal plants andTheir conservation status in Mecha wereda West Gojam zone. Ethio.J. Biol. Sci.3(2);113-132.

Getahun A (1976). Some common medicinal and poisonous plants used in ethiopian folk medicine.Addis Ababa.

Getaneh S and Girma Z (2014). An ethnobotanical study of medicinal plants in Debre libanos woreda,Central Ethiopia.Afri.J.Sci.,8 (7).

Gidey M (2001).An Ethnobotanical study of medicinal plants used by the Zay people in Ethiopia.

Hedberg, I. and Edwards, S. (eds .). ,1989 . Flora of Ethiopia and Eritrea .vol.3, Pittosporaceae to Araliaceae.

Hostettmann K and A Marston (2002). Twenty years of research into medicinal plants: Results and perspectives. Phytochemistry Reviews1: 275-285.

Hunde Debela, Asfaw Zemede and Kelbessa Ensermu (2004). Use and Management of ethno veterinary medicinal plants usedBy indigenous people in "Boset". Welenchiti area. Ethio.J. Biol. Sci.3(2);113-132.

Hunde, Debela, Asfaw, Zemede, Kelbessa, Ensermu (2004). Use and management of ethno veterinary medicinal plants used By indigenous people in "Boset". Welenchiti area. Ethio. J.Biol.Sci.3(2) ;113-132.Dery.B.B. ; Ofsynia. R.

Janzen, J.M. 1981 The Need for a Taxonomy of Health in the Study of Mrican Therapeutics. Social Science and Medicine. 12(2);121-129. Martin, G.J., 1995. Ethnobotany: a method Manual. Chapman and Hall,London.

Joy P, Thomas J, Mathew S, Skaria, B (1998).Medicinal plants.Aromatic and Medicinal Plants Research Station.Kerala agricultural university.

Khandel A, Ganguly S., Bajaj A., and Khan S. (2012). New Records, Ethno-pharmacological Applications \& Indigenous Uses of Gloriosa superba L. (Glory lily) Practices by Tribes of Pachmarhi Biosphere Reserve, Madhya Pradesh, Central India. Nature and Science, 10(5).

Kibebew Fassil (2001). Utilization and Conservation of Medicinal plants in Ethiopia. In proceeding of the workshop on Development Utilization of Herbal Remedies in Ethiopia; EthiopianHealth and nutrition Institute. Addis Ababa. 46-52.

Martin, G. J. (1995). Ethnobotany: A method Manual. A 'People and Plant conservation manual. Champman and Hall.London. Pp.268.

Megersa M Asfaw, Z Kelbessa, E, Beyene A,and Woldeab B (2013). An ethnobotanical study of medicinal plants in Wayu Tuka District, East Welega Zone of Oromia Regional State, West Ethiopia. $J$ of Ethnobiology and Ethnomedicine,9:68

Megersa M Asfaw, Z Kelbessa, E, Beyene A,and Woldeab B (2013). An ethnobotanical study of medicinal plants in Wayu Tuka District, East Welega Zone of Oromia Regional State, West Ethiopia. J of Ethnobiology and Ethnomedicine,9:68

Pankhurt, R., 2006. Traditional Ethiopian knowledge of medicine And surgery; an introduction of sources. OrganizationSocial science research in eastern and southern Africa (OSSREA).

UNEP (1995). Global biodiversity assessment. United Nations Environment Program. Workshop on Biodiversity Conservation and Sustainable Use of Medicil Plants in Ethiopia. 28 April-01 may 1998. IBCR. Addis Ababa.

World Health Organisation. Traditional Medicin; WHO: Geneva, 2002; Seehttp;//www.Who.int/medicines/library/ trm/trm Start eng. Pdf. Last accessed26/11/2004.

Yadav H (2013). Medicinal plants in folk medicine system of Ethiopia. J. Poisonous. Med.Plant. Res., 1(1):7-11.

Yirga G (2010). Assessment of traditional medicinal plants in Endrta District, South-eastern Tigray, Northern Ethiopia. Afr. J. Plant Sci., 4(7) : 255-260.

Yirga, Gidey and Samuel, Zeraburk (2005). Ethno botanical study of traditional plants in Gindebert district. Western Etiopia.62.

Zenebe G, Zerihun M, and Solomon Z (2012).An Ethnobotanical Study of Medicinal Plants in Asgede Tsimbila District, Northwestern Tigray, Northern Ethiopia.Ethnobotany Research \& Applications. 